\title{
МОДЕРНІЗАЦІЯ ПОСТМОДЕРНУ: ПРИЧИНИ ТА ПЕРСПЕКТИВИ
}

\author{
С.В.Куцепал \\ У філософському дискурсі другої половини минулого століття без- \\ заперечним «володарем дум» можна вважати постмодерн (або його \\ ще називають постмодернізм, хоча ці два терміни несуть різне семан- \\ тичне навантаження ${ }^{1}$ ). Постмодерн у сфері сучасного філософського \\ дискурсу постає у трьох основних іпостасях: по-перше, як одна з най- \\ більш розпіарених та задіяних філософем; по-друге, як певний тип \\ світогляду; по-трете, як методологія дослідження значного комплексу \\ соціально-філософських проблем, що вдало конкуруе з синергетикою \\ та призабутою під уламками тоталітарних ідеологій діалектикою. \\ Одним 3 магістральних напрямків постмодерної філософії постае \\ дослідження у сфері гуманітарних наук, прагнення до розкриття та \\ розуміння сутності й перспектив сучасних соціальних трансформацій \\ та процесів, створення футурологічних прогнозів стосовно розвитку \\ соціуму у координатах глобалізації, інформатизації та віртуалізації. \\ Це й не дивно, адже у постмодерній картині світу відсутня будь-яка \\ система пріоритетів та жорстка структурованість реальності, відки- \\ дається ієрархічний порядок. Тоталізуючий дискурс Модерну заміню- \\ еться культом плюральності та фрагментарності, визнанням нескін- \\ чених змін та відмінностей, переконанням, що реальність неможливо \\ описати за допомогою лінійних термінів. \\ Оцінки феномену постмодерну діаметрально протилежні-від \\ прийняття (В. Вельш, П. Козловські, Г. Кюнг, С. Сулейман, І. Хассан,

\footnotetext{
${ }^{1}$ Більш детально про це див.: Куцепал С.В. Постмодернізм-зваблива та нерозкрита таємниця // Філософські обрії.- Вип. 21. - Кнїв-Полтава, 2009.-С.314.
} \\ Актуальні проблеми духовності: \\ зб. наук. праць / Ред.: Я.В. Шрамко \\ Вип. 11. - Кривий Ріг, 2010, 115-123 \\ ISSN 2076-7382


О. Вайнштейн, С.Зенкін, Г.Косіков, Л.Маркова, Л.Філіппов, А.Якимович, Г. Заїченко, В.Лях, В.Лук'янець, О. Соболь, М. Савельєва, О.Хома, В.Ярошовець та ін.) до заперечення ( абсолютно або з певними умовами) його основних положень (В. Савчук, М. Епштейн ${ }^{2}$, Г. Тульчинський, А. Сокал).

Яскравим прикладом постмодерного підходу до постмодерну можна вважати книжку Ричарда Аппіньянезі «Знайомтесь: Постмодернізм» [1], опубліковану в серії інтелектуальних коміксів англійського видавництва Icon Books. Автор простежуе генеалогію постмодернізму в мистецтві та філософії, у цікавій та пізнавальній формі викладае його теорію й історію, розглядає деконструкцію, семіотику, структуралізм, розкриває сутність поглядів Ж. Дерріда, М.Фуко, Р.Барта, К. Леві-Стросса, Ю. Крістєвої, Ж. Лакана, Ж.-Ф. Ліотара.

Абсолютно інакше як пародія на постмодернізм написана і сприймаеться робота $\mathrm{A}$. Сокала «Transgressing the Boundaries: Towards as Transformative Hermeneutics of Quantum Gravity» $(1996)^{3}$, де автор намагається довести наукову неспроможність будь-яких постмодерно орієнтованих теорій.

Варто також зупинитися на характеристиці книги Н.А. Терещенко та Н.М.Шатунової «Постмодерн як ситуація філософствування» (СПб., 2003), де автори намагаються надати грунтовний аналіз філософії постмодерну в цілому та її основних тематичних утворень (проблема нового розуміння реальності, проблема співвідношення модерну та постмодерну, розуміння людини, «ототожнення людини 3 текстом», онтологізм мови тощо). Автори дотепно зауважують, що потрібно народитися французом, щоб розмірковувати про постмодерн. Власна національна належність не заважає їм прагнути до подібних розмислів, які породжують думку, що сутність постмодерну - це сукупність (інколи еклектична) різноманітних шарів і утворень, які немож.ливо помислити в органічній єдності, звинувачують постмодернізм у розмитості кордонів між реальністю та спробами теоретизування, між теорією і практикою. Сучасна ситуація культури уявляеться як «парад культурно-історичних форм», котрі існують незалежно одна від одної.

Постмодерн розуміється авторами як постійний супутник модерну, який пригадуе й відроджує фрагменти минулого, прагне врівноважити

\footnotetext{
${ }^{2}$ Див. напрпклад: Савчуж $B$. , છлитейн $M$. Речи па поминках постмодерна. Режим доступа: http://j2100.narod.ru/epsht_l.htm.

3нтелектуальна провокапія А. Сокала стала причиною своєрідної інтелектуальної війнп між «сокалістамп» та «постмодерністамп» стосовно проблем епістемолоГii.
} 
минуле з метою позбавлення крайнощів, що можуть призвести до саморуйнації, «перетворює минуле на власне Інше». Як наслідок - співпадають «учора» та «завтра», реабілітується теперішне, заперечуеться поетапність і перспективність прогресу, «нове виникае як поеднання вже завершених фрагментів буття». Автори визначають найбільш болючі моменти постмодерної проблематики. Однією з таких, на їхню думку, е проблема суб'єкта, котрий проявляеться в діалозі з Іншим, але цей Інший мае не реальну, а віртуальну природу.

Велика увага приділяється ототожненню тексту з людиною, онтологізації духовного життя, проблемі репрезентації реальності. Стверджується, що постмодернізм залишився у полоні класичного уявлення про людину. «Якщо свідомість розуміється як сукупність мовних практик, котрі далеко не завжди носять індивідуальний характер, то сутність людини все ж є пред-заданою..., людина завжди вибирає, але вибирає із наявного. У цьому плані постмодернізм ... продовжує, хоча й в збоченому вигляді, класичну версію людства» [6, с.68].

Незважаючи на значну кількість досліджень, присвячених постмодерну, до цього часу відсутня едина оцінка џього напрямку, наслідком чого стало прагнення деяких мислителів модернізувати постмодерн, підправити певні його положення, надати нове наповнення тим концептам, що стали «візитівкою» постмодерну - «деконструкція», «децентрація», «письмо», «гра», «іронія», «смерть автора», «слід», «хаотичність» тощо.

Тріумфальний поступ постмодерна на теренах Західної, а потім і Східної Європи розпочинаеться у другій половині минулого століття, проте еволюція та евристична наповненість цього поняття досить своерідні. Так, спочатку постмодерн представлений в основному ідеями французьких метрів (М. Фуко, Р.Барт, Ж. Дерріда, Ж. Дельоз, Ж.Ф. Ліотар), уявляється методологією гуманітарного пізнання та посттравневим ${ }^{4}$ світоглядом західного інтелектуального загалу; в кінці минулого століття, що характеризується терміном «постіндустріальне суспільство», зусиллями 3. Баумана, П. Козловські, Ж. Ліповецькі та ін., постмодерн отримуе статус методології аналізу соціальних систем та дослідження історії. Початок нинішнього століття розкрив нові горизонти для постмодерну - аналіз та інтерпретація релігії, мистецтва, науки, а також використання теоретичного інструментарію постмодерну у царині гендерних досліджень.

Ключовим моментом у зміні відношення до постмодерну та пошу-

\footnotetext{
${ }^{4}$ Мағоться на увазі події травня 1968 року у Франції.
} 
ку нової філософеми можна вважати 1997 рік, коли у Чикаго відбувається масштабна конференція «After-postmodernism», серед учасників якої - Ю.Т. Гендлін, Р.А.Шведер, Г.Б. Медісон, Й. Ангермюллер, Т. Сордас та ін. Центральним завданням конференції стало вироблення стратегії подальшого мислення. «Невже ми назавжди приречені мислити у рамках децентрації, дестабілізації, розриву, невизначеності, апорії? У більшості випадків зазначений підхід блокуе мислення, призводить до неможливості подальшого мислення. [...] Ми прагнемо розсунути межі постмодерного мислення і думати далі-вже за рамками постмодерну» [9].

На теренах пострадянського філософського простору зусиллями poсійських (В. Куріцин, М. Епштейн, Г. Тульчинський) та українських (Д.Руденко, Н. Загурська, О. Андрєєва) дослідників народжується концепт «постпостмодерн», покликаний покінчити 3 децентрацією, знайти можливість та обгрунтувати необхідність центрації «децентрованого поля номадичних сингулярностей» (М. Можейко), віднайдення суб'єктивної самототожності людини, «можливості створення нових, не фіксованих центрів у сфері іманентного» [5, с. 353], при цьому кожен центр перетворюється на один 3 можливих способів сприйняття світу. «Центр является не жестко фиксированным, а центром-проекцией, вершиной, точкой зрения на бесконечно развертываюшийся мир» $[5$, c. 354-355].

Зупинимося, зокрема, на двох розвідках - «Філософія можливого» М.Н. Епштейна (СПб., 2001) та «Постлюдська персонологія: нові перспективи свободи та раціональності» Г.Л. Тульчинського (СПб., 2002). Автор першої праці вважає, що такі етапи розвитку філософії, як деконструктивізм, критицизм тощо на сьогодні повністю вичерпали себе, а тому сучасна філософія має відмовитися від прагнення пояснювати i змінювати світ, її головне призначення - помножувати можливі світи, що утворюються навколо того єдиного світу, в якому ми зараз живемо. Предметом філософії оголошуеться світобудова як сукупність можливих світів (див.: [8, с. 75]). Другий розділ праці М. Епштейна присвячений аналізу деконструкції Ж. Дерріда ${ }^{5}$ та визначенню її переваг і

\footnotetext{
${ }^{5}$ Нагадаємо, що Ж. Дерріда маніфестував завдання реконструкпії як подолання «метафізики присутності», яка базувалася на так званих бінарних опозиціях, де один елемент домінував над інпим, та принципі дентрапіі. К. Дерріда «оголосив війну» принципу центрації, прагнучи знищити саму ідею первннғості, замінити différence на difference, що надае змогу легітимізувати співіснування множини рівноправних смислових утворень, утверджуе знаковість замість опозптивної відмінності.
} 
недоліків. Визнаючи величезний вплив ідей мислителя на західну філософську думку останньої третини XX ст., автор стверджуе, що деконструкція при іï маніфестованому антиметафізичному пафосі все ж по-новому відроджуе ті метафізичні засади, які піддае критиці (див.: [8, с. 146]). Недоліком філософської системи Ж. Дерріда М. Епштейн вважае ігнорування останнім категорії «можливість» як елемента системи своїх категорій, тому замість метафізики потойбічного виникае метафізика поцейбічного (див.: [8, с. 177]), відбувається інверсія метафізики.

Г.Л. Тульчинський у своїй книзі «Постлюдська персонологія: нові перспективи свободи та раціональності» розглядае постмодернізм лише як черговий елемент множини «-ізмів», котрий уже не може зацікавити нікого, окрім його власних представників та нечисленних фанатів.

Г.Л. Тульчинський також $є$ співавтором книги «Перспективи метафізики: класична та посткласична метафізика на перетині століть» (СПб., 2000), де стверджуеться, що виникнення культури і філософії постмодернізму пов'язане не лише визнаними причинами на кшталт «кінця історії» чи «смерті Бога», але й з глибоким переживанням «шизофренічності» соціального буття, яка постійно збільшуеться. Саме 3 цих причин «філософія постмодерну найчастіше сприймається як ясне та безсумнівне заперечення будь-яких традицій... Це принципова настанова, а не зовнішня аура етапуючої свідомості, „відчута“" i сприйнята постмодернізмом. Геній заперечення, що маскуеться у розслаблюючих лінощах думки, насправді стає камертоном та модулятором постмодерністичної ідеї» [4, с. 327].

Варто зупинитися на розробках російського дослідника В. Куріцина ${ }^{6}$, який досить виважено та толерантно аналізуе співвідношення постмодерну та постпостмодерну, на відміну від М. Епштейна та Г. Тульчинського, і не заперечуе того факту, що ситуація постмодерну, визначена й охарактеризована ЖK.-Ф.Ліотаром, все ще залишається актуальною. Проте, російський дослідник підкореговуе версію французького метра і вказуе на існування двох вимірів ${ }^{7}$ ситуації постмодерну - початковий, «героїчний», що характеризуеться бурхливим розви-

\footnotetext{
${ }^{6}$ Див.: Курицин В. Великие мифы и скромные деконструкции // Октябрь.1996. - Na 8. - С.171-187; Курицин B. Время множить приставки // Октябрь.1997. - № 7. - С. 178-183; Курицин В. Постмодернизм: новая первобытная культура Курицин // Новый мир.-1992. - №2.-С.225-241; Куриция В. Русский литературный постмодернизм. - Режнм доступа: htt://www.gueiman.ru/postmod.

${ }^{7}$ В. Курідин називає їх «етапами» ситуації постмодерну.
} 
тком теоретизування, та більш спокійний, який отримуе назву постпостмодерн. При цьому головною причиною виникнення постпостмодерну дослідник вважае толерантність, плюралізм постмодерну, визнання рівноправності вертикалі та горизонталі. «Мягкий постмодернистский тезис о том, что вертикаль - это горизонталь, что все культуры равноправны и равнокачественны независимо от исторической традиции, экономической успешности и количественности, привел к террору меньшинств» $[3$, с. 178].

Своєрідним виходом 3 кризи постмодерну стає спроба його модернізації - постпостмодерн, де дещо змінюеться відношення до певних проблем та понять. Так у наробках сучасних дослідників постпостмодерного зразка змінюється трактування ролі хаосу у створенні картини світу. Якщо у фантасмагоричних побудовах Ж. Дельоза та $\Phi$. Гваттарі хаос знаходить притулок у номадологічному ${ }^{8}$ вимірі їхньої онтології, сутність якої у відмові від структурної організації буття та від розуміння простору як утвореного множиною семантичних та аксіологічно визначених елементів (точок), пов'язаних дискретно-диференційованим зв'язком, і саме цим підриваються нормативні принципи раціональності як незмінного, вічного порядку речей, то у постпостмодерні ситуація змінюється, хаотичність наділяється несистемними, динамічними, «мерехтливими» центрами. Виникає туга за модерним суб'єктом, який був наділений значними творчими потенціями, що актуалізує необхідність виникнення «суб'єктивної деміургї̈ (Д. Руденко), коли кожен суб'єкт зможе стати новим центром свого власного можливого світу, скласти власну, цілісну «мозаїку із фрагментів буття». Завдяки віртуалізації виникає нова естетична картина світу, де вже немає місця хаосу, а, навпаки, наявна ідеальна впорядкованість.

У контексті даного дослідження варто більш детально зупинитися на тлумаченні віртуальності та віртуальної реальності, оскільки зазначені феномени активно використовуються у філософемі постпостмодерну. Доволі довгий час вважалося, що віртуальна реальність це породження та квінтесенція постмодерну, проте, В. Ємелін у своїй роботі «Віртуальна реальність та симулякри» ставить під сумнів дане твердження. Він доводить, що саме віртуальна реальність - найуспішніший проект модерну, оскільки їі внутрішня структура характеризується чітко визначеною ієрархічністю, побудовою за моделлю

\footnotetext{
${ }^{8}$ Згідно з Ж. Дельозом до номади залучені не лише дисперсні спли, що діють у певному інтелектуальному полі, а й жлібідозні» інтенції суб'екта, по перетинають та перемішують будь-яку структуру, завдяки дьому домінантою стае поняття множинності як того, що виражае відмінність в усій множині можливих значень.
} 
дерева, підкореністю розуму (див.: [2]). Це твердження звучить певним дисонансом до думок знаних дослідників віртуалістики. Так, наприклад, С. Хорунжий визначає віртуальність як недорід буття, недовизначеність та недовтіленість, сферу буття «духовних симулякрів», під дією яких розмиваються межі власного Я та відбуваеться віртуалізація свідомості. Він наголошує: «Виртуальная реальность - недовыступившее, недо-рожденное бытие, и одновременно - бытие, не имеющее рода, не достигшее „постановки в род“» [4, с.349]. У зв'язку 3 вищезазначеним варто пригадати один 3 найважливіших концептів Ж. Дельоза та Ф.Гваттарі - ризому, яка протистоїть «вертикальній іммобільності» класичної метафори дерева і замінюе $\dddot{1}$ на мобільну горизонтальність кореневої системи. Класична філософія розробила і свято зберігала модель світу у вигляді дерева, головними ознаками якої були вертикальний зв'язок між небом та землею, лінійна односпрямованість розвитку, детермінованість сходження, бінарні відношення «уліво-вправо», «високо-низько». Ж. Дельоз та Ф. Гваттарі у своїй книзі «Ризома» виділяють два різновиди цієї моделі - «деревокорінь» та «система-корінець, або мочковатий корінь». Перша модель має стрижневі корені з периферійним недихотомічним розповсюдженням гілок і характеризується роздвоєнням Єдиного, що підкоряється законам бінарної логіки. Важлива роль при цьому належить суб'єктові, а об'єкт повністю підкоряеться умові корінної єдності-едності стрижня, котрий підтримуе вторинні корені.

Система-корінець відрізняється від першої тим, що її головний корінь або знищений, або недостатньо розвинутий, тому він виступае тією основою, на яку надбудовуються вторинні корені, утворюючи у такий спосіб множинності. Звичайно, такі методологічні установки призводять до того, що світ перетворюється на хаос, місце головного кореня займае мочковата система корінців. Як бачимо, обидві моделі прагнуть утворити множинність лише одним шляхом - добавляючи нові зовнішні якості до того виду множини, що є вже наявним. Модель дерева постае трансцендентною, іерархічною структурою, котра може отримати розвиток лише завдяки бінарним опозиціям, тому невирішуємим стає завдання створити множинність не шляхом додавання нових одиничностей, а навпаки, виділяючи єдине із множини. Така операція доступна лише у ризомі, альтернативній моделі неявного та неексклюзивного зв'язку світу, котру засновують Ж. Дельоз та Ф. Гваттарі. Ризома як приховане стебло радикально відрізняється від коренів та коренців, це цибулини, клубні. Сама по собі ризома мае різні форми, починаючи від її поверхневого розширення і до її конкретного 
втілення в цибулинах та клубенях. Ризома - це термін, запозичений 3 ботаніки, який означає кореневу систему рослини, позбавлену центрального (головного) відростку, в результаті чого сітка переплетеного коріння $є$ суббстанціонально рівнозначною і утворюе перервну поверхню, позбавлену глибини, і відповідно, позбавлену й суб'єкта, що виконує контрольно-наглядові функції. Зрозуміло, що ця модель не має i центру, а тому не може бути представлена у вигляді обмежувальної структури. Ризома проникае в будь-які сфери, створюе несподівані зв'язки між дивергентними лініями розвитку, постійно породжуе відмінності, нав'язує або навпаки руйнує лінії зв'язку, одночасно диференціюючи їх і таким чином знищуючи відмінності.

Як бачимо, постмодерн розділив сумну долю своїх попередників, різноманітних «-ізмів», які намагалися переробити та переформатувати наступні філософські концепції. Постпостмодерн виникає у кінці XX століття і оголошуе пріоритетними питання про можливості подолання релятивізму, про заміну деконструкції конструюванням, про перегляд традиційних філософських понять (істина, розум) у рамках комунікативної практики, позбавивши їх і метафізичного есенціалізму, і постмодерного релятивізму, про реінкарнацію трансцендентального означуваного, а разом з ним значення та реальності присутності, неодноразово похованих теоретиками постмодерну.

\section{1 Бібліографія}

[1] Аnпиньянези Р. Знакомьтесь: Постмодернизм. - СПб.: Академический проект, 2004.

[2] Емелин B. Виртуальная реальность и симулякры. - Режим доступа: http://emelin.narod.ru/virtual.htm.

[3] Курицин В. Время множить приставки // Октябрь.-1997.№ 7. - C. 178-183.

[4] Перспективы метафизики: классическая и неклассическая метафизика на рубеже веков. - СПб.: Алетейя, 2001.

[5] Руденко Д.И. Игра: книга, которая (не) получилась // Философия языка: в границах и вне границ. - Харьков: Око, 1999.- С. 329374.

[6] Терещенко H.А., Шатунова Т.М. Постмодерн как ситуация философствования. - СПб.: Алетейя, 2003. 
[7] Хоружий С.С. О старом и новом.-СПб.: Алетейя, 2000.

[8] Эпитейн М.Н. Философия возможного. - СПб.: Алетейя, 2001.

[9] Gendlin E.T., Shweder R.A. Conference on After Postmodernismhttp://www.focusing.org/apm.htm

Надіиันла до редакцї 18 січня 2010 р. 